\title{
Experience of temporary discharge from the inpatient palliative care unit: A nationwide post- bereavement survey for end-of-life cancer patients
}

Go Sekimoto

Sekimoto Clinic

Sakiko Aso

Shizuoka Cancer Center: Shizuoka Kenritsu Shizuoka Gan Center

Naoko Hayashi

St Luke's International University: Sei Roka Kokusai Daigaku

Keiko Tamura

Kyoto University: Kyoto Daigaku

Chieko Yamamoto

Kasugai Rehabilitation Hospital

Maho Aoyama

Tohoku University: Tohoku Daigaku

Tatsuya Morita

Seirei Mikatahara Hospital: Seirei Mikatahara Byoin

Yoshiyuki Kizawa

Kobe University: Kobe Daigaku

Satoru Tsuneto

Kyoto University: Kyoto Daigaku

Yasuo Shima

Tsukuba Medical Center Hospital

Mitsunori Miyashita ( $\nabla$ miya@med.tohoku.ac.jp)

Tohoku University Graduate School of Medicine https://orcid.org/0000-0002-7637-0409

\section{Research Article}

Keywords: palliative care, neoplasms, temporary discharge, inpatient palliative care unit, postbereavement survey

Posted Date: March 11th, 2021

DOl: https://doi.org/10.21203/rs.3.rs-190093/v1 
License: (c) (i) This work is licensed under a Creative Commons Attribution 4.0 International License. Read Full License

Version of Record: A version of this preprint was published at Asia-Pacific Journal of Oncology Nursing on April 1st, 2022. See the published version at https://doi.org/10.1016/j.apjon.2022.03.010. 


\section{Abstract}

Background: Some patients admitted to an inpatient palliative care unit (PCU), and who were discharged temporarily to home, later died at the PCU. The experiences of these patients and their families during temporary discharge are unclear.

Methods: This study was part of a nationwide post-bereavement survey, the Japan Hospice and Palliative Care Evaluation 3 study. We sent questionnaires to the bereaved relatives of cancer patients who died in a PCU in 2018.

Results: Of the 968 questionnaires sent, 571 (59\%) were analyzed. Sixteen percent of the patients experienced temporary discharge from the PCU. Seventy-two percent of the bereaved family reported that the patients said, "I am happy to be discharged to home." Between $22 \%$ and $37 \%$ of the patients reported an improvement in their condition after discharge. Family caregivers' recognition of the better quality of the patient's life at home and hospital doctors' assurances of re-hospitalization whenever necessary, were significantly associated with positive experiences of temporary discharge.

Conclusion: Bereaved family members recognized temporary discharge as a positive experience for both the patient and the family. Appropriate home palliative care and discharge planning contribute to positive experiences after discharge.

\section{Introduction}

Japanese specialized palliative care commenced with the incorporation of inpatient palliative care units (PCUs) into the national medical insurance system [1]. In 2014, 13\% of all cancer deaths occurred in the PCU [2]. A Japanese PCU has two roles: as a place of death and for symptom control [3]. In the latter case, patients who had relief from distressing symptoms were discharged to home or were transferred to another facility. In fact, $16 \%$ of the patients who were admitted to a PCU were discharged alive [2]; however, this has been estimated to be lower than that reported by acute palliative care units in the US and Canada $[4,5]$. A previous nationwide survey showed that $72 \%$ of patients who were discharged from PCU were cared for at home, $12 \%$ in an acute hospital, and $6 \%$ in a care facility; while $39 \%$ died at home, $39 \%$ in a PCU and $15 \%$ in an acute hospital [6]. These results suggest that $39 \%$ of the discharges were temporary, and that they needed to be re-admitted to a PCU again because of worsened symptoms or an increased care burden at home.

However, many Japanese prefer staying at home in the terminal phase $[7,8]$, with both patients and families preferring home care despite the possibility of readmission because of worsened symptoms or care burden. Therefore, the Japanese health authority founded the PCUs to ensure a coordinated discharge, cooperation with community-based medical institutions which deliver home care, and to accept emergency re-admission of the patients from home care [9]. 
Although home was found to be the most commonly preferred place of care for terminal patients worldwide [10], positive and negative effects and benefits of home care have been reported $[11,12]$. Several post-bereavement surveys have reported that home deaths resulted in good deaths being achieved in Japan $[13,14]$. However, most of these findings were limited to home deaths; experiences of patients who were discharged temporarily from a PCU and re-admitted and who then subsequently died in a PCU have not been reported. Although clinicians have felt the benefits of temporary discharge empirically, there has been no evidence supporting these benefits.

Therefore, in this study, we aimed to explore the experience of patients who were discharged temporarily from a PCU, from the perspective of the bereaved family members.

\section{Methods}

This study was part of a nationwide survey of bereaved family members of cancer patients that aimed at evaluating the quality of end-of-life care in Japan (the Japan Hospice and Palliative Care Evaluation Study 3 (J-HOPE3) conducted in 2018 [15]. The J-HOPE3 study was a multicenter questionnaire survey of bereaved family members of cancer patients who died in a PCU. Ethical approval for the study was granted by the Institutional Review Boards of the Tohoku University (No. 2013-1-334) and all the participating institutions.

\section{Participants and procedures}

The participants of this study were 968 bereaved family members of cancer patients who died in a PCU. The inclusion criteria were as follows: 1 ) the patient died of cancer, 2) the patient was aged 20 years or older, 3 ) the bereaved family member was aged 20 years or older, and 4) the duration of the last hospitalization was three days or more. The exclusion criteria were as follows: 1 ) the bereaved family members could not be identified; 2 ) death was associated with the treatment; 3 ) the participant experienced serious psychological distress, as determined by the primary physician, and 4) the participant was incapable of completing the self-reported questionnaire because of health issues such as cognitive impairment or visual disability.

The PCUs where the patients were hospitalized and then died sent the questionnaire to bereaved family members between May and July 2014.

\section{Questionnaires}

Experience of discharge by what the patient had said

We asked the bereaved family members about the experience of discharge by what the patient had said; whether the patient had said "I am happy to be discharged to home," "I regret being discharged to home," or "both." 
We asked the bereaved family members about their perceptions of the temporary discharge, patients' circumstances compared to being hospitalized, and family circumstances compared to the patient being hospitalized. We developed 17 questions based on a literature review, interviews with 10 bereaved family members, and discussions among researchers. Responses were rated on a 5-point Likert scale ( $1=$ disagree, 2 = somewhat disagree, 3 = unsure, 4 = somewhat agree, 5 = agree) .

Circumstances of the patient and family caregiver before and after temporary discharge.

We asked the bereaved family members about the circumstances of the patients and family caregivers before and after the temporary discharge; for example, the preferences of the patients and family members on discharging to home; the physical, mental, and social status of the patients and families before discharge; and the consultation and support by health care professionals before and after discharge. We developed 26 questions based on a literature review, interviews with 10 bereaved family members, and discussions among researchers. We asked the participants to respond to either 1: agree or 2: disagree.

\section{Participant characteristics}

We extracted the patient's age, sex, primary cancer sites, and duration of the last hospital stay from the medical records. Using the questionnaire, we obtained the bereaved family member's age, gender, relationships with the patient, frequencies of visits to the patient during the last hospitalization, their health status during the last hospitalization, and end-of-life discussions with the physician and the patient.

\section{Statistical analysis}

First, we compared the characteristics of the patients and bereaved family members between the discharged and non-discharged groups using the Chi-squared test. Second, for the patients who were discharged to home temporarily, we used descriptive statistics to analyze their experiences after the temporary discharge as well as the circumstances of the patients and family caregivers before and after the temporary discharge. Lastly, we explored associations between having positive experiences of discharge by what the patient had said, namely, "I am happy to be discharged to home," the experience after the temporary discharge and the circumstances of the patients and family caregivers before and after temporary discharge using the Chi-square test or Fisher's exact test, as appropriate. All statistical tests were two-tailed with a significance level of 0.05 , and all analyses were conducted using SPSS Statistics for Windows, version 25.0 (IBM Corp., Tokyo, Japan).

\section{Results}

Of the 968 questionnaires mailed to bereaved family members of cancer patients, 711 were returned. Of these, 74 refused to answer, 25 were excluded because of violation of the inclusion criteria, and 41 did not 
provide answers about the presence or absence of temporary discharge from the PCU. Therefore, 571 questionnaires were analyzed (59\%).

Of the 571 respondents, 90 (15.8\%) answered that they had experienced temporary discharge from a PCU. Durations from discharge to home to re-admission to a PCU were as follows; 25 patients $(25.6 \%)$ stayed at home for less than 3 days, 9 (10.0\%) for $4-6$ days, 11 (12.2\%) for $7-13$ days, 16 (17.8\%) for $1--29$ days, and 29 (32.2\%) for more than 30 days.

Table 1 shows the participants' characteristics according to whether they were in the discharged or nondischarged groups. Sex (male: $P=0.05)$, longer disease duration of cancer $(P=0.004)$, better mental health status of caregivers during the last hospitalization $(P=0.04)$, and frequent attendance of family members during the last hospitalization $(P=0.01)$ were associated with discharge.

With regard to the experience of discharge by what the patient had said, $72 \%$ of the patients reported: "I am happy to be discharged to home," $1 \%$ reported, "I regret being discharged to home," $4 \%$ reported, "both," and $20 \%$ did not say anything about the experience of discharge.

The family members' perceptions of the experiences of temporary discharge are shown in Table 2. Seventy-eight percent answered: "both patient and family felt happy by staying at home together; followed by "patient and family members were able to spend time together peacefully (71\%)," "the time spent together at home was precious (68\%)," "family members were able to spend more time with the patient $(66 \%)$," "family members were satisfied that they were able to take care of the patient at home (60\%)." Between $22 \%$ to $37 \%$ of the participants reported improvement in the patients' circumstances and between $15 \%$ to $66 \%$ reported improvements in the families' circumstances compared to those reported for patients that were hospitalized.

The circumstances of the patients and family caregivers before and after temporary discharge are shown in Table 3. Regarding the circumstances of the patients and the families before temporary discharge, $88 \%$ of the participants answered: "the family wanted to spend time with the patient." As for the preparation for temporary discharge, $87 \%$ answered "the hospital doctor promised that the patient could be rehospitalized if necessary." As for medical support after discharge, $91 \%$ answered, "the patient was able to be re-hospitalized on the patient's or family's request."

We showed statistically significant associations between having a positive experience of discharge by what the patient had said, the family members' perceptions of the experiences of temporary discharge and the circumstances of the patients and family caregivers before and after temporary discharge (Table 4). The patients who were discharged to home, compared to those who were not, answered "the time spent together at home was precious $(P=0.005)$," "the patient was able to have the time that he/she had wished to spend $(P=0.02)$," "the patient had smiled more $(P=0.02)$," "the patient had slept better $(P=0.05)$," "the patient had an increased appetite $(P=0.05)$," "the family members were able to spend more time with the patient $(P=0.01)$," "the patient showed obvious desire to be discharged to home $(P=0.001)$," "the hospital doctor promised that the patient could be re-hospitalized whenever and if necessary $(P=0.001)$," 
"the hospital doctor strongly recommended that the patient be discharged $(P=0.02)$," "the patient and family members had a chance to try staying at home overnight for trial $(P=0.02)$," "the patient was able to be re-hospitalized on patient's or family's request $(P=0.008)$," "the home visit doctors, nurses, and care manager were well coordinated during the patient's care $(P=0.04)$," " and reported more positive experiences.

\section{Discussion}

The major findings of this study were as follows: 1) $16 \%$ of the patients who died in the PCUs experienced temporary discharge; 2 ) most of the patients and bereaved family members appreciated their experience of temporary discharge and between $22 \%$ and $37 \%$ of them reported improvements in the patients' conditions after discharge, 3) the family caregivers' recognition of the better quality of the patient's life at home and the hospital doctors' assurances of re-hospitalization whenever and if necessary were strongly associated with positive experiences by what the patient had said.

With respect to the factors related to the duration of the temporary discharge, significant variables were found to be almost similar to those of a previous study that explored factors related to discharge from a PCU [16-18]. In addition, the results of the circumstances of the patients and family caregivers during the temporary discharge revealed that most patients were in desirable circumstances, which were almost similar to the factors that would contribute to home death [19]. These results suggest that discharge planning for home death can contribute to patients and families' positive experiences at the end of life, regardless of the place of death.

We reported the first nationwide quantitative study on the experience of temporary discharge, although clinicians have felt the benefits of temporary discharge empirically. Although re-admission in the terminal stage is sometimes regarded as one of the negative quality indicators [20]; family caregivers sometimes considered caring for the patients at home as an achievement and that admission or re-admission and dying in the hospital were not considered negatively [12]. These results support our can recommendation for temporary discharge even if the patient was expected to stay a long time at home.

Approximately $20 \%$ of the patients had improved physical conditions such as pain and appetite. Although several studies have shown that symptom management was better in the institutional hospice setting than in the home setting [21,22], staying at home may have had a positive impact on the relieve of physical symptoms in some patients [23]. These benefits may have resulted in the better survival in home palliative care settings $[5,24,25]$.

In addition, the explanatory analysis of the factors associated with positive experience by what the patient had said and the hospital doctors' assurance of re-hospitalization during discharge counseling, emphasized the importance of providing appropriate home palliative care after discharge.

\section{Limitations}


This study had some limitations. First, the response rate was not very high, and we could analyze only 90 questionnaires. Second, the bereaved family members' opinions might not have reflected the patients' experiences. Lastly, we analyzed the patients who died at the PCU, and we excluded patients whose last hospitalization was less than 3 days. We did not analyze the experience of patients and family caregivers who died without having been in a PCU or were readmitted at the very end of life.

\section{Conclusions}

Bereaved family members recognized temporary discharge as a positive experience for both the patient and family. Appropriate home palliative care and discharge planning contributed to positive experiences after discharge.

\section{Declarations}

\section{Funding:}

This study was supported by the Hospice Palliative Care Japan.

\section{Conflicts of interest:}

The authors have no conflicts of interest to declare that are relevant to the content of this article.

\section{Ethics approval:}

Ethical approval for the study was granted by the Institutional Review Boards of the Tohoku University (No. 2013-1-334) and all the participating institutions.

\section{Consent to participate:}

Responses to the questionnaire were regarded as consent.

\section{Consent for publication:}

Responses to the questionnaire were regarded as consent.

\section{Availability of data and material:}

We can provide the data if needed.

\section{Authors' contributions:}

All authors contributed to the study conception and design. Data collection were performed by Go Sekimoto, Maho Aoyama, and Mitsunori Miyashita. Data analysis were performed by Go Sekimoto, Sakiko Aso, and Mitsunori Miyashita. The first draft of the manuscript was written by Go Sekimoto and 
all authors commented on previous versions of the manuscript. All authors read and approved the final manuscript.

\section{References}

1. Tsuneto S (2013) Past, present, and future of palliative care in Japan. Jpn J Clin Oncol 43:17-21. https://doi.org/10.1093/jjco/hys188

2. Kizawa Y, Shima Y, Takamiya Y, Tsuneto S, Miyashita M, Yamazaki F (2020) White paper of hospice and palliative care 2020. Seikaisya, Tokyo

3. Morita T, Miyashita M, Tsuneto S, Shima Y (2008) Palliative care in Japan: shifting from the stage of disease to the intensity of suffering. J Pain Symptom Manag 36:e6-e7. https://doi.org/10.1016/j.jpainsymman.2008.06.004

4. Hausner D, Kevork N, Pope A, Hannon B, Bryson J, Lau J, Rodin G, Le LW, Zimmermann C (2018) Factors associated with discharge disposition on an acute palliative care unit. Support Care Cancer 26:3951-3958. https://doi.org/10.1007/s00520-018-4274-2

5. Hui D, Elsayem A, Palla S, De La Cruz M, Li Z, Yennurajalingam S, Bruera E (2010) Discharge outcomes and survival of patients with advanced cancer admitted to an acute palliative care unit at a comprehensive cancer center. J Palliat Med 13:49-57. https://doi.org/10.1089/.jpm.2009.0166

6. Odagiri T, Morita T, Itoh H, Yamada Y, Hashimoto A, Sekimoto T, Baba M, Narimoto K, Suzuki T, Tsujimura Y (2017) Nationwide Survey to Clarify where the Terminally ill Cancer Patients who Admitted to Palliative Care Units Discharged and Finally Died. Gan No Rinsho 63:159-165

7. Fukui S, Yoshiuchi K, Fujita J, Sawai M, Watanabe M (2011) Japanese people's preference for place of end-of-life care and death: a population-based nationwide survey. J Pain Symptom Manag 42:882-892. https://doi.org/10.1016/j.jpainsymman.2011.02.024

8. Sanjo M, Miyashita M, Morita T, Hirai K, Kawa M, Akechi T, Uchitomi Y (2007) Preferences regarding end-of-life cancer care and associations with good-death concepts: a population-based survey in Japan. Ann Oncol 18:1539-1547. https://doi.org/10.1093/annonc/mdm199

9. Mori M, Morita T (2016) Advances in hospice and palliative care in Japan: a review paper. Korean J Hosp Palliat Care 19:283-291. https://doi.org/10.14475/kjhpc.2016.19.4.283

10. Gomes B, Calanzani N, Gysels M, Hall S, Higginson IJ (2013) Heterogeneity and changes in preferences for dying at home: a systematic review. BMC Palliat Care 12:7. https://doi.org/10.1186/1472-684X-12-7

11. Higginson IJ, Sarmento VP, Calanzani N, Benalia H, Gomes B (2013) Dying at home-is it better: a narrative appraisal of the state of the science. Palliat Med 27:918-924.

https://doi.org/10.1177/0269216313487940

12. Woodman C, Baillie J, Sivell S (2016) The preferences and perspectives of family caregivers towards place of care for their relatives at the end-of-life. A systematic review and thematic synthesis of the 
qualitative evidence. BMJ Support Palliat Care 6:418-429. https://doi.org/10.1136/bmjspcare-2014000794

13. Kinoshita H, Maeda I, Morita T, Miyashita M, Yamagishi A, Shirahige Y, Takebayashi T, Yamaguchi T, Igarashi A, Eguchi K (2015) Place of death and the differences in patient quality of death and dying and caregiver burden. J Clin Oncol 33:357-363. https://doi.org/10.1200/JC0.2014.55.7355

14. Miyashita M, Morita T, Sato K, Tsuneto S, Shima Y (2015) A nationwide survey of quality of end-oflife cancer care in designated cancer Centers, Inpatient Palliative Care Units, and Home Hospices in Japan. The J-Hope Study J PAIN Symptom Manag 50:38-47.e33

15. Aoyama M, Morita T, Kizawa Y, Tsuneto S, Shima Y, Miyashita M (2017) The Japan HOspice and palliative care evaluation Study 3: study design, characteristics of participants and participating institutions, and response rates. Am J Hosp Palliat Care 34:654-664. https://doi.org/10.1177/1049909116646336

16. Amano K, Nishiuchi Y, Baba M, Kawasaki M, Nakajima S, Wakayama H, Watakabe A, Kunimoto H, Morita T (2014) The determinants of patients in a palliative care unit being discharged home in Japan. Am J Hosp Palliat Care 31:244-246. https://doi.org/10.1177/1049909113484384

17. Miura H, Matsumoto Y, Okizaki A, Oishi M, Szuki T, Motonaga S, Sakamoto H, Sekimoto A, Abe K, Kinoshita $\mathrm{H}$ (2013) Retrospective study of the factors tended to transfer to palliative home care from palliative care unit at a comprehensive cancer center in Japan. Palliat Care Res 8:107-115 (in Japanese)

18. Miyashita M, Arai K, Yamada Y, Owada M, Sasahara T, Kawa M, Mukaiyama T (2009) Discharge from a palliative care unit: prevalence and related factors from a retrospective study in Japan. J Palliat Med 12:142-149. https://doi.org/10.1089/jpm.2008.0216

19. Gomes B, Higginson IJ (2006) Factors influencing death at home in terminally ill patients with cancer: systematic review.[see comment]. BMJ 332:515-521 [erratum appears in BMJ 2006 Apr 29 332:1012]

20. Earle CC, Park ER, Lai B, Weeks JC, Ayanian JZ, Block S (2003) Identifying potential indicators of the quality of end-of-life cancer care from administrative data. J Clin Oncol 21:1133-1138. https://doi.org/10.1200/JC0.2003.03.059

21. Eagar K, Clapham SP, Allingham SF (2020) Palliative care is effective: but hospital symptom outcomes superior. BMJ Support Palliat Care 10:186-190. https://doi.org/10.1136/bmjspcare-2018001534

22. Tang ST (2002) Influencing factors of place of death among home care patients with cancer in Taiwan. Cancer Nurs 25:158-166. https://doi.org/10.1097/00002820-200204000-00013

23. Pinzón LC, Claus M, Zepf KI, Fischbeck S, Weber M (2012) Symptom prevalence in the last days of life in Germany: the role of place of death. Am J Hosp Palliat Care 29:431-437. https://doi.org/10.1177/1049909111425228

24. Hamano J, Yamaguchi T, Maeda I, Suga A, Hisanaga T, Ishihara T, Iwashita T, Kaneishi K, Kawagoe S, Kuriyama T, Maeda T, Mori I, Nakajima N, Nishi T, Sakurai H, Shimoyama S, Shinjo T, Shirayama H, 
Yamada T, Morita T (2016) Multicenter cohort study on the survival time of cancer patients dying at home or in a hospital: does place matter? Cancer 122:1453-1460.

https://doi.org/10.1002/cncr.29844

25. Murakami N, Tanabe K, Morita T, Kadoya S, Shimada M, Ishiguro K, Endo N, Sawada K, Fujikawa Y, Takashima R, Amemiya Y, lida H, Koseki S, Yasuda H, Kashii T (2015) Going back to home to die: does it make a difference to patient survival? BMC Palliat Care 14:7. https://doi.org/10.1186/s12904-015-0003-5

\section{Tables}


Table 1. Participant Characteristics

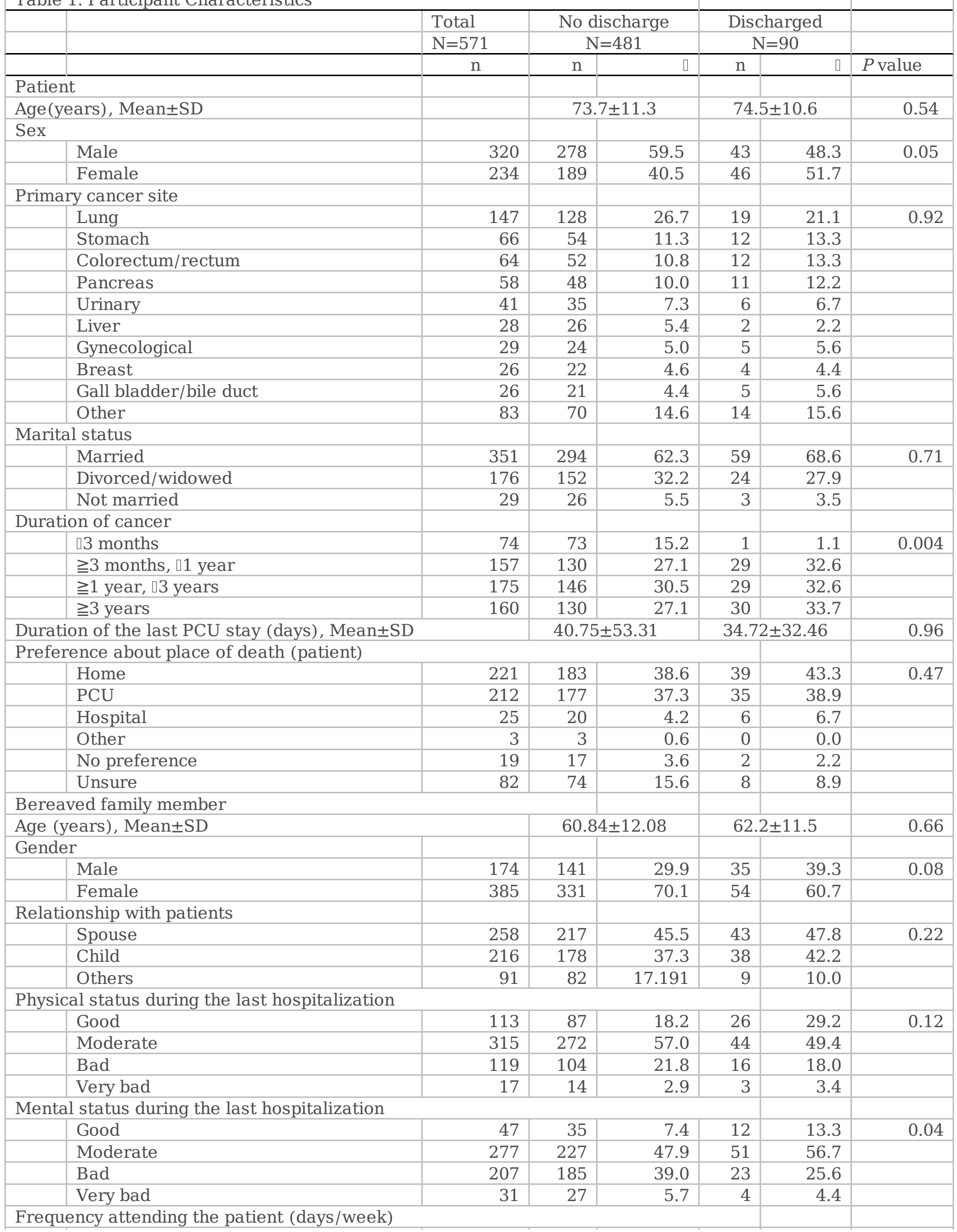




\begin{tabular}{|l|r|r|r|r|r|r|}
\hline Everyday & 369 & 322 & 67.1 & 48 & 53.3 & 0.01 \\
\hline $4-6$ & 77 & 60 & 12.5 & 17 & 18.9 & \\
\hline $1-3$ & 86 & 70 & 14.6 & 16 & 17.8 & \\
\hline 1 & 36 & 28 & 5.8 & 9 & 10.0 & \\
\hline Preference about place of death (family) & & & & & & \\
\hline Home & 129 & 103 & 21.8 & 26 & 29.5 & 0.62 \\
\hline PCU & 370 & 314 & 66.4 & 56 & 63.6 & \\
\hline Hospital & 25 & 22 & 4.7 & 3 & 3.4 & \\
\hline Other & 2 & 2 & 0.4 & 0 & 0.0 & \\
\hline No preference & 17 & 15 & 3.2 & 2 & 2.3 & \\
\hline Unsure & 18 & 17 & 3.6 & 1 & 1.1 & \\
\hline
\end{tabular}

SD, standard deviation; PUC: inpatient palliative care unit

Table 2. Family member's perceptions of the experiences of temporary discharge

\begin{tabular}{|c|c|c|c|}
\hline & $\begin{array}{l}\text { Agree, somewhat } \\
\text { agree(\%) }\end{array}$ & Unsure(\%) & $\begin{array}{l}\text { Somewhat } \\
\text { disagree, } \\
\text { disagree(\%) }\end{array}$ \\
\hline \multicolumn{4}{|l|}{ Family's perceptions about temporary discharge } \\
\hline $\begin{array}{l}\text { Both the patient and the family felt happy by staying } \\
\text { at home together. }(\mathrm{N}=87)\end{array}$ & 78 & 15 & 7 \\
\hline $\begin{array}{l}\text { The patient and the family were able to spend time } \\
\text { together peacefully. }(\mathrm{N}=87)\end{array}$ & 71 & 18 & 10 \\
\hline $\begin{array}{l}\text { The time spent together at home was precious. } \\
(\mathrm{N}=87)\end{array}$ & 68 & 24 & 8 \\
\hline $\begin{array}{l}\text { Family were satisfied about taking care of the } \\
\text { patient at home. }(\mathrm{N}=87)\end{array}$ & 60 & 32 & 8 \\
\hline $\begin{array}{l}\text { Time spent together at home had strengthened } \\
\text { their family bonding. }(\mathrm{N}=86)\end{array}$ & 53 & 34 & 13 \\
\hline $\begin{array}{l}\text { Family regretted that the patient left home and was } \\
\text { re-hospitalized. }(\mathrm{N}=87)\end{array}$ & 26 & 40 & 33 \\
\hline $\begin{array}{l}\text { Family felt that the patient was forced to be } \\
\text { discharged. }(\mathrm{N}=86)\end{array}$ & 13 & 14 & 73 \\
\hline \multicolumn{4}{|l|}{ Patient's condition compared to being hospitalized } \\
\hline $\begin{array}{l}\text { Patient was able to have the time he/she had } \\
\text { wished to spend. }(\mathrm{N}=87)\end{array}$ & 37 & 31 & 32 \\
\hline Patient had smiled more. $(\mathrm{N}=87)$ & 36 & 41 & 23 \\
\hline Patient had slept better. $(\mathrm{N}=86)$ & 23 & 41 & 36 \\
\hline Patient had increased appetite. $(\mathrm{N}=86)$ & 22 & 29 & 49 \\
\hline Patient expressed less pain. $(\mathrm{N}=85)$ & 22 & 29 & 48 \\
\hline \multicolumn{4}{|l|}{$\begin{array}{l}\text { Family condition compared to patient being } \\
\text { hospitalized }\end{array}$} \\
\hline $\begin{array}{l}\text { Family were able to spend more time with the } \\
\text { patient. }(\mathrm{N}=87)\end{array}$ & 66 & 14 & 21 \\
\hline Family felt more burden to care the patient. $(\mathrm{N}=87)$ & 46 & 31 & 23 \\
\hline Family felt peaceful. $(\mathrm{N}=87)$ & 28 & 39 & 33 \\
\hline Family was able to have more free time. $(\mathrm{N}=87)$ & 15 & 45 & 40 \\
\hline Family had slept better. $(\mathrm{N}=87)$ & 15 & 39 & 46 \\
\hline
\end{tabular}


Table 3. Circumstances of the patient and family caregiver before and after temporary discharge.

\begin{tabular}{|c|c|c|}
\hline & Agree $(\%)$ & Disagree(\%) \\
\hline \multicolumn{3}{|l|}{ Circumstances of the patient and family before temporary discharge } \\
\hline Family wanted to spend time with the patient. $(\mathrm{N}=86)$ & 88 & 12 \\
\hline Patient showed obvious desire to be discharged to home. $(\mathrm{N}=86)$ & 81 & 19 \\
\hline $\begin{array}{l}\text { Family had understood that the patient would not stay long at home. } \\
(\mathrm{N}=85)\end{array}$ & 81 & 19 \\
\hline Pain and other symptoms were controlled. $(\mathrm{N}=84)$ & 80 & 20 \\
\hline $\begin{array}{l}\text { Family had thought that the patient could be hospitalized in the PCU as long } \\
\text { as they wished. }(\mathrm{N}=85)\end{array}$ & 65 & 35 \\
\hline Family wished to take care of the patient at home. $(\mathrm{N}=81)$ & 54 & 46 \\
\hline Patient needed medical treatment such as injection and drainage. $(\mathrm{N}=86)$ & 28 & 72 \\
\hline $\begin{array}{l}\text { There was disagreement among family members about the patient's } \\
\text { discharge. }(\mathrm{N}=86)\end{array}$ & 6 & 94 \\
\hline \multicolumn{3}{|l|}{ Preparation of temporary discharge } \\
\hline $\begin{array}{l}\text { The hospital doctor promised that the patient could be re-hospitalized } \\
\text { whenever if necessary }(\mathrm{N}=84)\end{array}$ & 87 & 13 \\
\hline $\begin{array}{l}\text { The hospital doctor informed that the home visit clinics and hospital can } \\
\text { provide consultation at any time of the day. }(\mathrm{N}=81)\end{array}$ & 85 & 15 \\
\hline $\begin{array}{l}\text { Family could consult with the hospital staffs about the patient's daily life } \\
\text { and home care services after being discharged. }(\mathrm{N}=81)\end{array}$ & 79 & 21 \\
\hline $\begin{array}{l}\text { The hospital doctor told the family the remaining life expectancy of the } \\
\text { patient. }(\mathrm{N}=85)\end{array}$ & 59 & 41 \\
\hline $\begin{array}{l}\text { Family had met the home visit doctors and nurses before being discharged. } \\
(\mathrm{N}=82)\end{array}$ & 59 & 41 \\
\hline $\begin{array}{l}\text { The hospital doctor strongly recommended that the patient be discharged. } \\
(\mathrm{N}=82)\end{array}$ & 44 & 56 \\
\hline $\begin{array}{l}\text { The patient and the family had a chance to try staying at home overnight for } \\
\text { trial. }(\mathrm{N}=82)\end{array}$ & 40 & 60 \\
\hline The home visit doctor was familiar with the hospital doctor. $(\mathrm{N}=75)$ & 39 & 61 \\
\hline The length of time staying at home was planned in advance. $(\mathrm{N}=84)$ & 32 & 68 \\
\hline \multicolumn{3}{|l|}{ Medical support after discharge } \\
\hline $\begin{array}{l}\text { The patient was able to be re-hospitalized on the patient's or family's } \\
\text { request. }(\mathrm{N}=78)\end{array}$ & 91 & 9 \\
\hline Home visit doctors and nurses gave attention to family as well. $(\mathrm{N}=75)$ & 84 & 16 \\
\hline $\begin{array}{l}\text { The home visit clinic or PCU provided consultation at any time of day. } \\
(\mathrm{N}=78)\end{array}$ & 82 & 18 \\
\hline $\begin{array}{l}\text { Home visit nursed had understanding of the values of the patient and } \\
\text { family. }(\mathrm{N}=72)\end{array}$ & 81 & 19 \\
\hline $\begin{array}{l}\text { Home visit doctors and nurses worked closely with the PCU staffs } \\
\text { regarding patient's care. }(\mathrm{N}=72)\end{array}$ & 78 & 22 \\
\hline $\begin{array}{l}\text { Home visit doctors had understanding of the values of the patient and } \\
\text { family. }(\mathrm{N}=71)\end{array}$ & 76 & 24 \\
\hline $\begin{array}{l}\text { Home visit doctors and nurses were able to relieve pain of the patient. } \\
(\mathrm{N}=72)\end{array}$ & 71 & 29 \\
\hline $\begin{array}{l}\text { Home visit doctors, nurses, and care manager were well coordinated during } \\
\text { the patient's care. }(\mathrm{N}=73)\end{array}$ & 70 & 30 \\
\hline $\begin{array}{l}\text { The patient used respite services, home help services, or volunteer } \\
\text { services. }(\mathrm{N}=76)\end{array}$ & 33 & 67 \\
\hline
\end{tabular}

PCU: palliative care unit 
Table 4. Associations between the positive experience of discharge by what the patient had said, and family member's perceptions of the experiences of temporary discharge and circumstances of patient and family caregiver before and after temporary discharge.

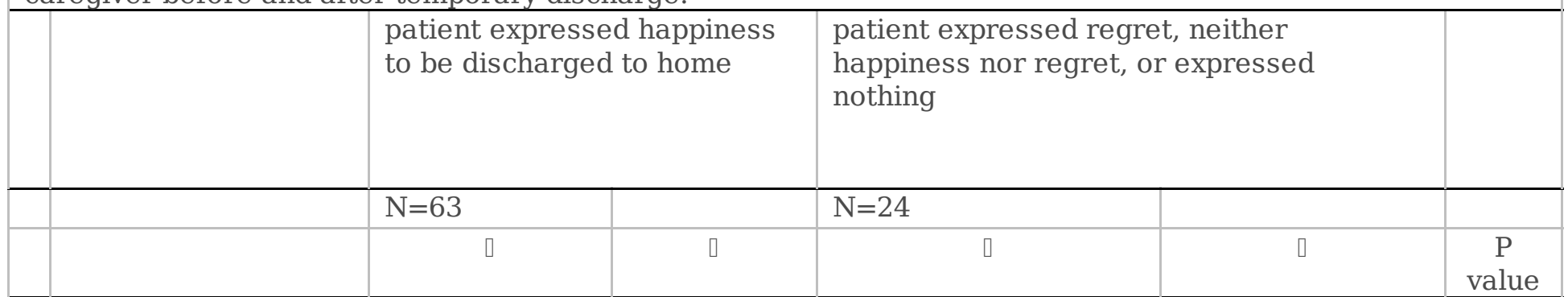

The time spent together at home was precious.

\begin{tabular}{|l|c|c|c|c|c|}
\hline $\begin{array}{l}\text { Agree; somewhat } \\
\text { agree }\end{array}$ & 47 & 81.0 & 11 & 19.0 & 0.005 \\
\hline $\begin{array}{l}\text { Unsure; somewhat } \\
\text { disagree; disagree }\end{array}$ & 14 & 51.9 & 13 & 48.1 & \\
\hline
\end{tabular}

The patient was able to have time he/she wished to spend.

\begin{tabular}{|l|c|c|c|c|c|}
\hline $\begin{array}{l}\text { Agree; somewhat } \\
\text { agree }\end{array}$ & 27 & 87.1 & 4 & 12.9 & 0.02 \\
\hline $\begin{array}{l}\text { Unsure; somewhat } \\
\text { disagree; disagree }\end{array}$ & 34 & 63.0 & 20 & 37.0 & \\
\hline
\end{tabular}

The patient had showed more smile.

\begin{tabular}{|l|c|c|c|c|c|}
\hline $\begin{array}{l}\text { Agree; somewhat } \\
\text { agree }\end{array}$ & 26 & 86.7 & 4 & 13.3 & 0.02 \\
\hline $\begin{array}{l}\text { Unsure; somewhat } \\
\text { disagree; disagree }\end{array}$ & 35 & 63.6 & 20 & 36.4 & \\
\hline $\begin{array}{l}\text { he patient had slept better. } \\
\begin{array}{l}\text { Agree; somewhat } \\
\text { agree }\end{array}\end{array} \quad 18$ & 90.0 & 2 & 10.0 & 0.05 \\
\hline $\begin{array}{l}\text { Unsure; somewhat } \\
\text { disagree; disagree }\end{array}$ & 43 & 67.2 & 21 & 32.8 & \\
\hline
\end{tabular}

The patient had increased appetite.

\begin{tabular}{|l|c|c|c|c|c|}
\hline $\begin{array}{l}\text { Agree; somewhat } \\
\text { agree }\end{array}$ & 22 & 88.0 & 3 & 12.0 & 0.05 \\
\hline $\begin{array}{l}\text { Unsure; somewhat } \\
\text { disagree; disagree }\end{array}$ & 38 & 66.7 & 19 & 33.3 & \\
\hline
\end{tabular}

The family were able to spend more time with the patient.

\begin{tabular}{|l|c|c|c|c|c|}
\hline $\begin{array}{l}\text { Agree; somewhat } \\
\text { agree }\end{array}$ & 45 & 80.4 & 11 & 19.6 & 0.01 \\
\hline $\begin{array}{l}\text { Unsure; somewhat } \\
\text { disagree; disagree }\end{array}$ & 16 & 55.2 & 13 & 44.8 & \\
\hline
\end{tabular}

The patient showed obvious desire to be discharged to home.

\begin{tabular}{|l|c|c|c|c|c|}
\hline Agree & 56 & 81.2 & 13 & 18.8 & 0.001 \\
\hline Disagree & 5 & 31.3 & 11 & 68.8 & \\
\hline
\end{tabular}

The hospital doctor promised that the patient could be re-hospitalized whenever and if necessary.

\begin{tabular}{|l|c|c|c|c|c|}
\hline Agree & 56 & 80.0 & 14 & 20.0 & 0.001 \\
\hline Disagree & 2 & 16.7 & 10 & 83.3 & \\
\hline
\end{tabular}

The hospital doctor strongly recommended the patient be discharged.

\begin{tabular}{|l|c|c|c|c|c|}
\hline Agree & 30 & 83.3 & 6 & 16.7 & 0.02 \\
\hline Disagree & 27 & 70.4 & 18 & 29.6 & \\
\hline
\end{tabular}

The patient and the family had a chance to try staying at home overnight.

\begin{tabular}{|l|l|l|l|l|l|}
\hline Agree & 27 & 87.1 & 4 & 12.9 & 0.02 \\
\hline Disagree & 31 & 62.0 & 19 & 38.0 & \\
\hline
\end{tabular}


The patient was able to be re-hospitalized on patient's or family's request.

\begin{tabular}{|c|c|c|c|c|c|}
\hline Agree & 53 & 75.7 & 17 & 24.3 & 0.008 \\
\hline Disagree & 2 & 28.6 & 5 & 71.4 & \\
\hline \multicolumn{6}{|c|}{ Home visit doctors and nurses and care manager were well coordinated during patient's care. } \\
\hline Agree & 39 & 70.8 & 11 & 29.2 & 0.04 \\
\hline Disagree & 12 & 54.5 & 10 & 45.5 & \\
\hline
\end{tabular}

